\title{
Bone Schwannoma
}

National Cancer Institute

\section{Source}

National Cancer Institute. Bone Schwannoma. NCI Thesaurus. Code C27476.

A very rare schwannoma of the bone. It is often located in the mandible and is well circumscribed. 